Provided for non-commercial research and education use. Not for reproduction, distribution or commercial use.

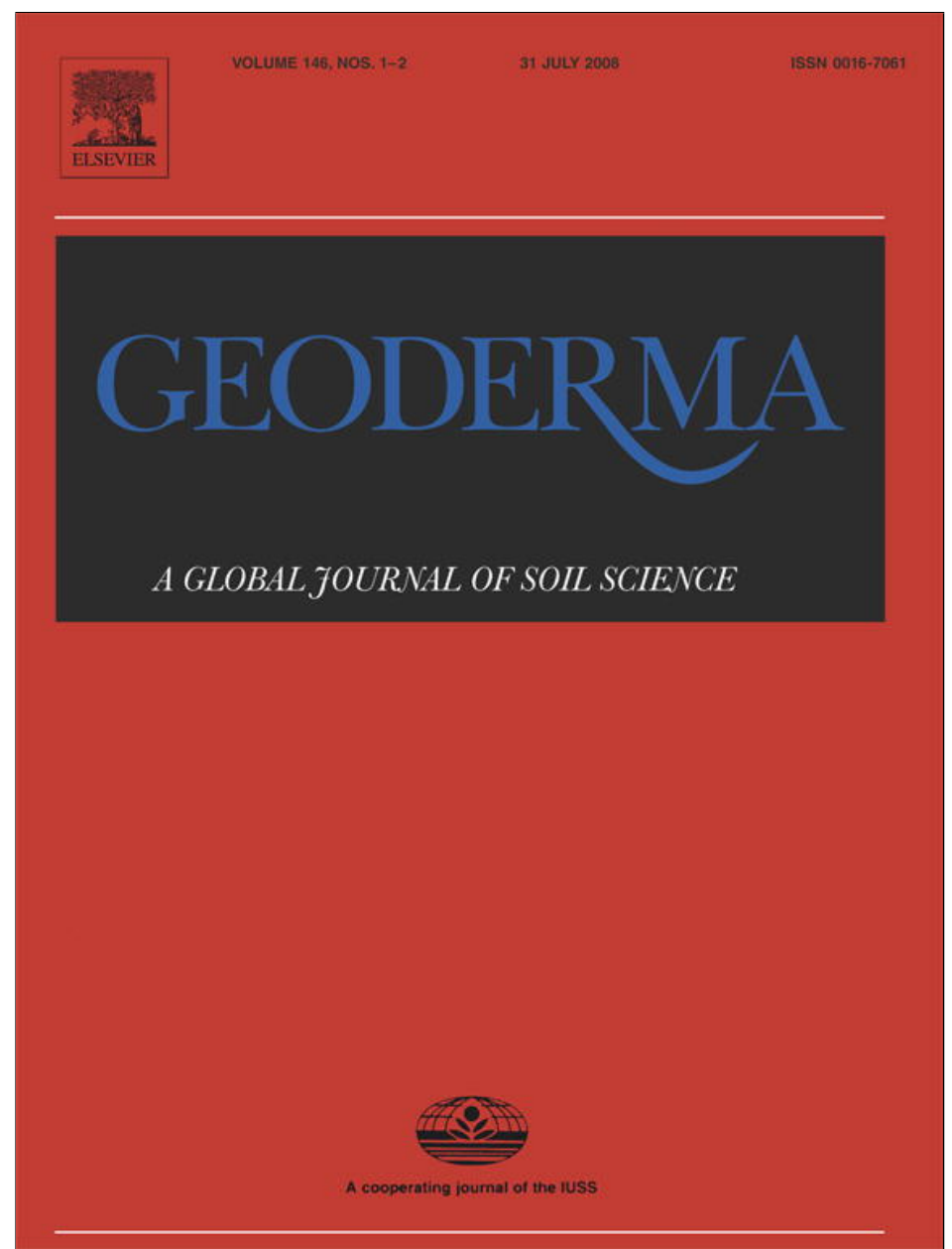

This article appeared in a journal published by Elsevier. The attached copy is furnished to the author for internal non-commercial research and education use, including for instruction at the authors institution and sharing with colleagues.

Other uses, including reproduction and distribution, or selling or licensing copies, or posting to personal, institutional or third party websites are prohibited.

In most cases authors are permitted to post their version of the article (e.g. in Word or Tex form) to their personal website or institutional repository. Authors requiring further information regarding Elsevier's archiving and manuscript policies are encouraged to visit:

http://www.elsevier.com/copyright 


\title{
The impact of soil temperature increase on organic matter and faunal properties in a frozen calcareous scree in the French Alps
}

\author{
Nathalie Cassagne*, Thomas Spiegelberger, Lauric Cécillon, Bernard Juvy, Jean-Jacques Brun \\ Cemagref Grenoble, Research Unit “Mountain Ecosystems”, 2 Rue de la Papeterie, BP 76, 38402 Saint-Martin-d'Hères, France
}

\section{A R T I C L E I N F O}

\section{Article history:}

Received 31 October 2007

Received in revised form 28 April 2008

Accepted 28 May 2008

Available online 10 July 2008

\section{Keywords:}

Climate change

Humus micromorphology

Humus thin sections

Oribatid mites

Collembola

\begin{abstract}
A B S T R A C T
We examine the effect of natural differences in soil temperature at two locations distant by approximately $500 \mathrm{~m}$ in the frozen scree of La Plagne en Chartreuse (Savoy, France). We determined humus properties, soil organisms and biologically mediated soil-forming processes in screes from a low part dominated by an open pine forest (OF, $1100 \mathrm{~m}$ asl) and in a top part covered by a dense pine forest (DF, $1200 \mathrm{~m}$ asl). Our results show a soil temperature increase of about $3.8{ }^{\circ} \mathrm{C}$ in the DF plot during June to October, but similar humus morphology at both plots. Soil $\mathrm{pH}$ was lower, and $\mathrm{C} / \mathrm{N}$ ratio higher in the DF plot. Soil faunal composition differed between DF and OF plots for some taxa. While the abundance of the Oribatid mites was higher, abundance of Collembola was significantly lower in the DF plot. As earthworm activity was scarce at the site, Oribatid mites and Collembola presumably play an important role in the humus microstructure which was confirmed by the analysis of the humus micro-aggregation. To date, changes in the pedofaunal communities did not alter the humus form which may be explained by the complexity of biotic soil interactions and the high functional redundancy of the soil fauna.
\end{abstract}

(c) 2008 Elsevier B.V. All rights reserved.

\section{Introduction}

According to the fourth assessment report of the Intergovernmental Panel on Climate Change, the Earth's climate has warmed by about $0.74{ }^{\circ} \mathrm{C}$ over the past century (http://www.ipcc.ch). Climate scenarios for the 21 st century predict further warming, with a best estimate temperature rise of $4.0^{\circ} \mathrm{C}$ (likely range is $2.4{ }^{\circ} \mathrm{C}$ to $6.4{ }^{\circ} \mathrm{C}$ ) for the high scenario A1F1 (IPCC, 2007). It has been suggested that these trends will be particularly pronounced at high latitudes altering snow cover, permafrost stability, growing season length, and productivity in arctic and boreal environments. Recent warming has already caused expansion of shrubs in vascular plant communities in many cold regions of the world (e.g. Theurillat and Guisan, 2001; Tape et al., 2006). In the European Alps, evidence of climatic change in the 20th century was observed through glacier retreat, decrease in snow-cover extent and earlier snowmelt (Beniston, 2006). Moreover, under the influence of climate warming (Post et al., 1982) cold biomes with high soil organic matter accumulation are of primary importance as possible sources of carbon emissions.

\footnotetext{
* Corresponding author. Fax: +33 476513803.

E-mail addresses: nat.cassagne@free.fr (N. Cassagne).

thomas.spiegelberger@cemagref.fr (T. Spiegelberger), lauric.cecillon@cemagref.fr

(L. Cécillon), bernard.juvy@cemagref.fr (B. Juvy), jean-jacques.brun@cemagref.fr
}

(J.-J. Brun).
Microclimatological studies have identified small alpine enclaves of screes with permafrost in many European mountains. Despite their distribution at much lower altitudes, they present distinctive features that would allow them to be classified into the alpine zone. The cold microclimatic conditions of these sites provide exceptional microhabitats with very thick raw humus (Gude et al., 2003) colonized by many cold living plants (Bertinelli et al., 1993) and periglacial relict species of non-vascular plants (Asta et al., 2001), beetles (Molenda, 1996), spiders (Ruzicka and Zacharda, 1994), and mites (Zacharda et al., 2005). These small-scale habitats, which are older than the surrounding biological matrix, act as refuge by supporting communities unable to survive elsewhere in the landscape. Such paleorefugia are expected to be particularly vulnerable to changes in their environmental conditions (e.g. global warming, but see Nekola, 1999 and Noss, 2001), and may therefore provide a sensitive indicator of climate change processes.

The presence of low-elevation permafrost sites is explained by a complex system of air circulation also called Balch ventilation (Thompson, 1962). Scree slopes formed of broken rocks have an intensive air circulation; with warm air outflow in the upper scree sections during winter, and cold air outflow in the lower sections during summer (Harris and Pedersen, 1998; Kneisel et al., 2000). This air-conditioning system creates a small-scaled spatial heterogeneity with temperatures (throughout the year) near freezing point at the lower part of the scree, which could form perennial ground ice. Furthermore, these severe thermal conditions are a major limitation of invertebrate distribution, which strongly influence the decomposition processes under such environmental constraints (Petersen and 
Luxton, 1982; Sjursen et al., 2005a). The distribution, abundance, and life cycles of soil decomposing animals, are all affected by soil temperature directly (e.g. through desiccation) and indirectly, through modifications in food resources and microhabitat (Setälä et al., 1995; Sulkava and Huhta, 2003; Huhta and Hanninen, 2001; Pflug and Wolters, 2001). These enclaves with alpine features therefore provide an appropriate environment in which to test the relationships between soil arthropods, plants and soil temperature.

In the present study, differences in soil temperature at the top and at the bottom of an alpine frozen scree is used to investigate changes in global warming on biological soil processes. The scree is used as a field laboratory to study long-term effects of soil temperature increase under natural conditions. Other variables such as precipitations, slope, exposure and bedrock are highly homogenous due to the short distance between the top and the bottom of the study area. Through field observations we examine the influence of variable soil temperature (like those predicted by IPCC global warming scenarios) on humus properties, soil organisms and biologically mediated soilforming processes. Our work addresses in particular two questions: 1) How do variations in temperature influence humus forms and soil arthropod distribution involved in organic matter decomposition? 2) Can pedofaunal changes alter humus form?

\section{Material and methods}

\subsection{The study site}

The study site of La Plagne $\left(45^{\circ} 27^{\prime} \mathrm{N}, 5^{\circ} 55^{\prime} \mathrm{E}\right)$ is situated in the Northern French Alps within the Réserve des Hauts de Chartreuse (Fig. 1). It is located on a limestone scree composed of crushed rocks from the Urgonian period (circa 130-125 million of years ago) with a sporadic permafrost caused by Balch ventilation. The scree has a slope of about $40^{\circ}$

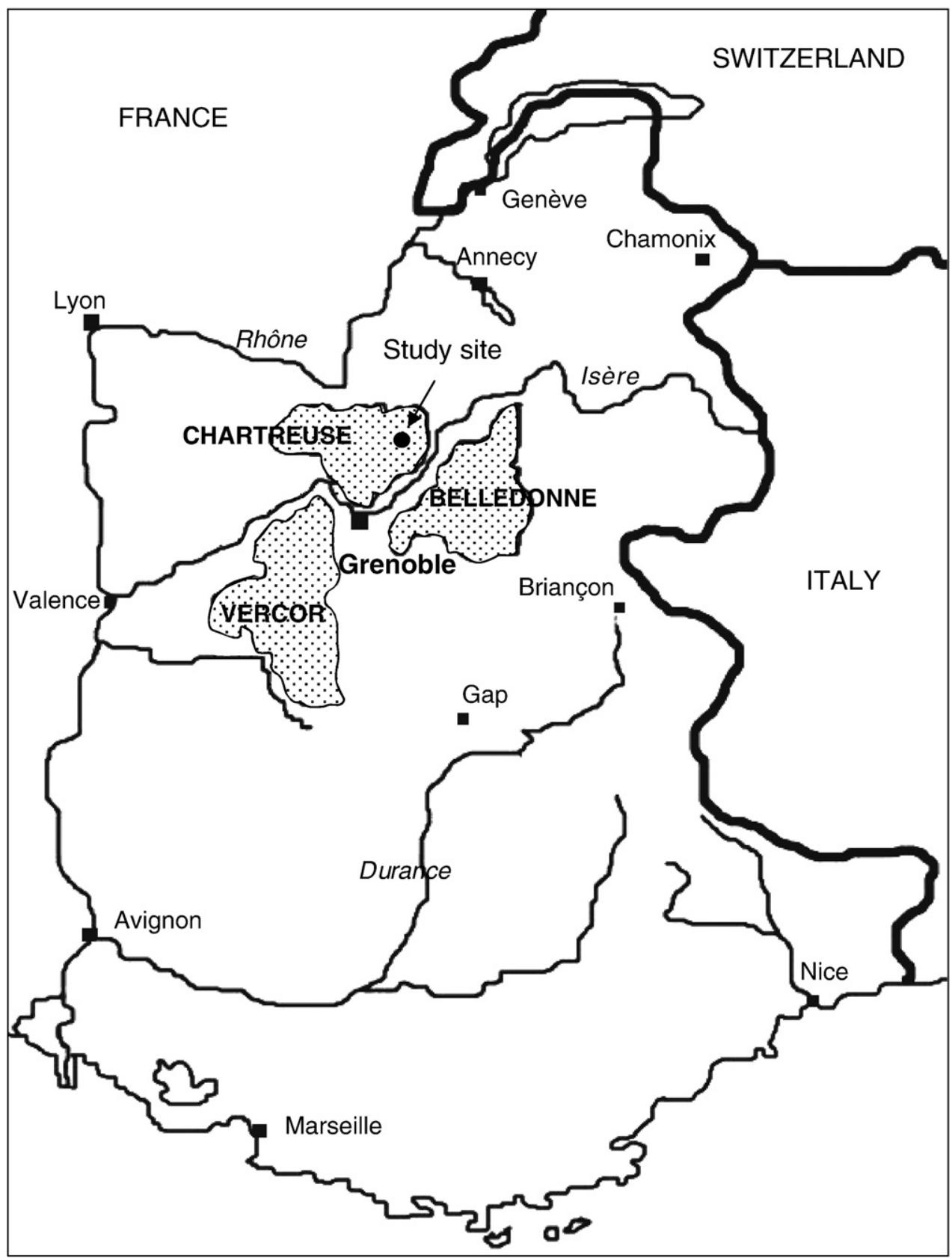

Fig. 1. Geographical location of the study site of La Plagne in the Northern French Alps. 
and is exposed to the North-Northwest. The climate of the region is characterized by a mean annual temperature of $7{ }^{\circ} \mathrm{C}$, abundant precipitations of $2000 \mathrm{~mm} /$ year and a long period of snow cover lasting from November to April. The site can be described as a cold alpine enclave in a montane ecosystem dominated by Mountain pine (Pinus uncinata Mill. ex Mirb.) forest and surrounded by climacic vegetation comprising of spruce and beech-fir forests. The soil can be considered a histosol, according to the USDA Soil Taxonomy (USDA, 1999), with a thick raw humus. The ground flora is a typical association of plants characteristic of raw humus (Rhododendron ferrugineum L., Vaccinium vitis-idaea L., V. myrtillus L.) with an important cover of mosses (Hylocomium splendens (Hedw.) B.,S.\&G., Rhytidiadelphus squarrosus (Hedw.) Warnst., Pleurozium schreberi (Brid.) Mitt., Dicranum scoparium Hedw., Polytricum formosum Hedw.) and lichens (Cladonia rangiferina (L.) Web., C. gracilis (L.) Willd., Cetraria islandica (L.) Ach.) accompanied by alpine calciphilic species (Dryas octopetala L., Saxifraga oppositifolia L., Carex sempervirens Villars or Arctostaphylos uva-ursi (L.) Spreng.).

\subsection{Experimental design}

Two experimental plots of approximately $150 \mathrm{~m}^{2}$ were set up at the top and at the bottom of the alpine part of the scree. The lower plot was situated at $1100 \mathrm{~m}$ asl in an open forest (OF), while at the higher plot (1200 $\mathrm{m}$ asl) a dense forest (DF) is present. The OF plot is characterized by dwarf Pinus uncinata with a maximal height of adult trees being 2-5 m. Crushed rocks are numerous and partly covered by alpine heliophilous species such as Carex sempervirens (15\% of cover) and Dryas octopetala (30\% of cover). Forest mosses (especially Hylocomium splendens) form an important layer between shrubs of Arctostaphylos uva-ursi, Salix retusa, Vaccinium myrtillus and the dominant Rhododendron ferrugineum and Vaccinium vitis idaea (both $20 \%$ of cover). The DF plot is characterized by a dense cover of Mountain pine trees reaching a height of 10 to $20 \mathrm{~m}$. Mosses form a quasi continuous layer and Rhododendron ferrugineum and Vaccinium vitis idaea are the principal shrubs with a cover of $25 \%$. Dryas octopetala is dominant (20\% of cover) where the tree cover is scarce.

Within these two plots, three subplots (circa $3 \times 6 \mathrm{~m}$ ) dominated by different vegetation (Dryas octopetala, Vaccinium vitis-idea, Rhododendron ferrugineum) were selected. In order to keep the pristine aspect of the scree labelled "Natura 2000", three random sample points were used in each subplot, at which humus forms were described along soil profiles (also used for monitoring of soil temperature). Soil and faunal samples were also collected. Sample points were distant from each other by at least $2 \mathrm{~m}$, resulting in a total of 18 sample points ( 2 altitudes $\times 3$ vegetation types $\times 3$ sample points).

\subsection{Sampling of humus forms and chemical analysis}

In July 2005 we described in situ the humus forms of each sample by identifying the L, F and H horizons through macro-morphological analysis of their structure, composition and other relevant properties using the Canadian classification (Green et al., 1993). Humus samples of a constant volume $\left(250 \mathrm{~cm}^{3}\right.$ ) were taken below $10 \mathrm{~cm}$ depth, brought back to the laboratory where they were sieved (mesh size $2 \mathrm{~mm}$ ) before being sent for soil analysis at INRA Arras. Soil pH was measured in $\mathrm{H}_{2} \mathrm{O}$, respecting a soil:solution ratio equal to $1: 2.5$. The cation exchange capacity (CEC) was determined by the Metson method (Metson, 1956). Exchangeable cations (Ca, Mg, K, Na) were measured by atomic absorption spectroscopy after ammonium acetate extraction (Thomas and Marshall, 1999). Organic carbon (ISO 10694,1999), total nitrogen (ISO 13878, 1999) and total $\mathrm{CaCO}_{3}$ (ISO 10693, 1999) was analysed. Soil temperature was manually monitored once a month from June to November 2005 along the soil profiles at $0,5,10,15,20$, and $25 \mathrm{~cm}$ depth using a $10 \mathrm{~cm}$ long probe (Hi765PWL, HANNA Instruments, Tanneries, France).

\subsection{Soil fauna investigation}

At the same time as humus was sampled, one humus core $(5.5 \mathrm{~cm}$ diameter and $10.5 \mathrm{~cm}$ deep) was taken next to each soil profile for faunal extraction in Berlese-Tullgren funnels (Schaller, 1968). From 21st June-5th September 2005, one pitfall trap (6 cm diameter and $8 \mathrm{~cm}$ deep) was placed in the vicinity of each soil profile and was emptied once every two weeks. Soil animals were classified into faunal taxa. In August 2005 a survey on earthworm abundance, similar to Callaham's and Hendrix's (1997) surveys, was performed on twelve $0.5 \times 0.5 \mathrm{~m}$-squares randomly chosen in the two plots. Squares were approximately $5 \mathrm{~m}$ apart from each other and the soil from each pit was separated into four fractions (litter, $0-5 \mathrm{~cm}, 5-15 \mathrm{~cm}$, and $15-$ $25 \mathrm{~cm}$ ) and hand-sorted for earthworms. Adult earthworms were identified to species, juveniles to genus.

\subsection{Study of biological aggregation by image analysis}

One humus block (Kubiena boxes of $8 \times 5 \times 3 \mathrm{~cm}$ ) was taken in all subplots dominated by Dryas at a depth of $10 \mathrm{~cm}$ at the transition between the $\mathrm{F}$ and $\mathrm{H}$ humus layers. Under Vaccinium and Rhododendron stands, humus blocks were taken at a depth of $10 \mathrm{~cm}$ in the F layer and at $20 \mathrm{~cm}$ in the $\mathrm{H}$ layer. The 30 samples (6 subplots under Dryas, 6 subplots $\times 2$ depths for Vaccinium and for Rhododendron) were stored at $5{ }^{\circ} \mathrm{C}$ until sent to the soil laboratory of Savoy University where thin sections of $25 \mu \mathrm{m}$ were performed. Thin sections were prepared from undisturbed blocks used in the standard procedure of drying samples by acetone exchange before resin impregnation (see FitzPatrick, 1980; Kooistra, 1991; Grieve et al., 2005).

Some difficulties have been encountered during the process of inclusion of the humus blocks and nearly half of the thin sections were unusable. We considered only 10 thin sections to respect a homogenization of the data between the two plots which allowed one description in each subplot. Image acquisition was carried out with a Sony Camera DXC-930P and aggregate structures (size and shape of particles) quantified by National Instruments Vision Assistant 8.0 software. For each thin section, 12 windows of $10 \times 10 \mathrm{~mm}$ (grid of 3 horizontal and 4 vertical windows) with a spatial resolution of $18 \mu \mathrm{m} /$ pixel were surveyed and digitized in a square grid of $768 \times 576$ pixels, with a spectral resolution of 256 grey levels. A morphological classification of the aggregation was established from the two measured parameters on each aggregate: its size, estimated from the diameter of its section in the binary image, and its form, estimated from the shape index (Pawluk, 1987; Bruneau et al., 2004). Special attention was given to faecal pellets of macrofaunal origin ( $>250 \mu \mathrm{m}$; thereon macroaggregates) and faecal pellets considered to be associated with meso- and micro-fauna $(<250 \mu \mathrm{m}$; thereon microaggregates) on the basis of their rounded shape with a shape index ranging from 0.67 to 0.95 according to Pawluk (1987). These two classes have been further subdivided into 8 size classes, relating to soil

Table 1

Size classes of biological aggregates with their shape index $\left(4 \pi\right.$ area/perimeter $\left.{ }^{2}\right)$ according to Pawluk (1987)

\begin{tabular}{llll}
\hline & Soil fauna organisms & Size & $\begin{array}{l}\text { Shape index, } \\
\text { (Pawluk, 1987) }\end{array}$ \\
\hline Microagregates $(<250 \mu \mathrm{m})$ & Acari or Collembola & $30-50 \mu \mathrm{m}$ & $0.87 \pm 0.06$ \\
& Collemba & $50-90 \mu \mathrm{m}$ & $0.88 \pm 0.04$ \\
& Collemba or Enchytreids & $90-125 \mu \mathrm{m}$ & $0.86 \pm 0.05$ \\
& Enchytreids & $125-250 \pm \mu \mathrm{m}$ & $0.88 \pm 0.05$ \\
Macroaggregates $(>250 \mu \mathrm{m})$ & Insecta larvae & $250-300 \pm \mu \mathrm{m}$ & $0,87 \pm 0,05$ \\
& (Coleoptera,Diptera) & & \\
& Diplopoda, Isopoda & $300-600 \pm \mu \mathrm{m}$ & $0.91 \pm 0.05$ \\
& Small Earthworm or & $600-940 \pm \mu \mathrm{m}$ & $0.84 \pm 0.06$ \\
& Diptera larvae & & \\
& Earthworm & $>1000 \pm \mu \mathrm{m}$ & \\
\hline
\end{tabular}




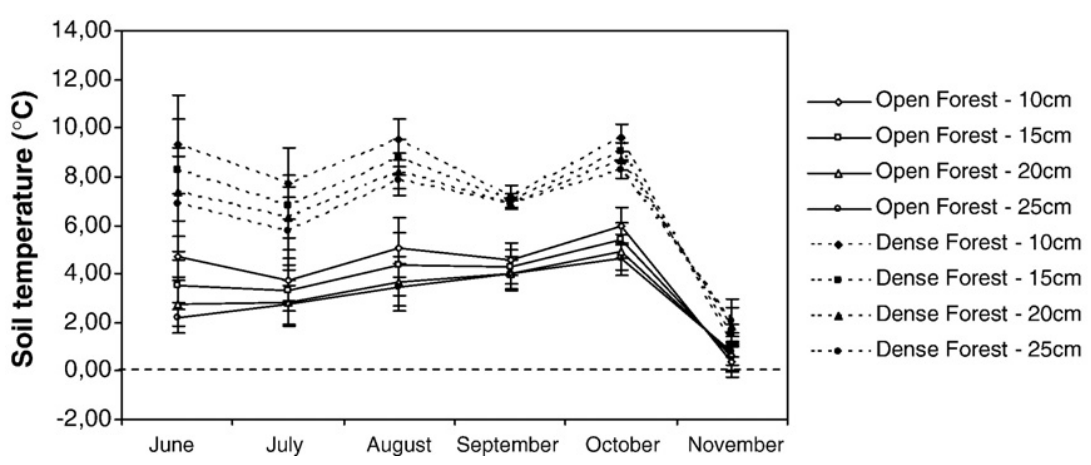

Fig. 2. Soil temperature variations (mean values with standard deviation) into soil profiles during the growing season (June to October) and November 2005 in the Open pine Forest (OF) and Dense pine Forest (DF) plots.

fauna organisms that have been referred to in several studies on humus features (Rusek, 1985; Pawluk, 1987) (Table 1). The results of biological aggregation were expressed as the area of the aggregate relative to the total image area.

\subsection{Statistical analysis}

Auto-correlation between the soil chemical variables was tested by Pearson correlation test. Differences in soil chemical properties, faunal groups and soil temperature between the two plots were analyzed using ANOVA models. Plot, vegetation in the subplot and its interactions were tested against the variation among random samples. For the analysis of the soil temperature, air temperature was introduced as a covariable and depth of the soil samples and its interaction with plot and vegetation was tested against the variation of the temperature per depth and sample, and time (month) and its interactions with the other factors against the error term. For earthworm analysis, ANOVAs were replaced by the non parametric Mann-Whitney $U$-test. Relationships between soil aggregation and biological activity were analysed by $t$-test to compare the plot effect, the humus horizon effect and the size of aggregates (macro- and micro-aggregation). Tukey or Fisher post-hoc test was used to discriminate between significant results within factors. We checked the normality of the data and applied $\log (n+1)$ or an arcsin $\sqrt{n}$ transformation when the normality was not respected. All statistical analyses were conducted using Statistica 7.1 software.

\section{Results}

\subsection{Soil temperature variations from -10 to $-25 \mathrm{~cm}$}

Soil temperature varied significantly between months $(p<0.001)$ and plots $(p<0.001)$ until November. In November, soil temperatures were similar at the DF and OF plots ( $p>0.1)$ and reached values near the freezing point in both plots (Fig. 2). Soil temperature was different at all depth except for the OF plots where soil temperature at $-20 \mathrm{~cm}$ and $-25 \mathrm{~cm}$ did not differ significantly $(p=0.20)$ during the study period. During the growing season from June to October, soil temperature was between $2.7^{\circ} \mathrm{C}$ (September) and $4.6{ }^{\circ} \mathrm{C}$ (June) higher in the DF-plot.

\subsection{Morphological description of humus forms}

Despite the differences in temperature from June to October, the soil profiles were similar at both plots (DF and OF). Both plots were composed of three horizons (L, Fm, Hh) which classify them among the Humimor humus according to the Canadian classification. The litter (L), which is composed of a mixture of pine needles and birch
Table 2

Relative abundance of the soil faunal groups per plot for pitfall traps

\begin{tabular}{|c|c|c|c|c|c|c|c|c|}
\hline & \multicolumn{2}{|c|}{ Pitfall traps } & \multicolumn{6}{|c|}{ Two-way ANOVA } \\
\hline & \multirow{2}{*}{$\begin{array}{l}\text { Open } \\
\text { Forest } \\
\text { Plot }\end{array}$} & \multirow{2}{*}{$\begin{array}{l}\text { Dense } \\
\text { Forest } \\
\text { Plot }\end{array}$} & \multicolumn{2}{|c|}{ Plot Effect } & \multicolumn{2}{|c|}{$\begin{array}{l}\text { Vegetation } \\
\text { effect }\end{array}$} & \multicolumn{2}{|c|}{ Interactions } \\
\hline & & & $F(1,84)$ & $P$ & $F(2,84)$ & $P$ & $F(2,84)$ & $P$ \\
\hline \multicolumn{9}{|l|}{ Mollusca } \\
\hline Gasteropoda & 0.04 & 0.21 & & ns & & ns & & ns \\
\hline Nematoda & 0.00 & 0.00 & & ns & & ns & & ns \\
\hline \multicolumn{9}{|l|}{ Oligocheta } \\
\hline Enchytraeidae & 0.00 & 0.00 & & ns & & ns & & ns \\
\hline \multicolumn{9}{|c|}{ Arthropoda crustacean } \\
\hline Isopoda & 0.08 & 0.90 & & ns & & ns & & ns \\
\hline \multicolumn{9}{|c|}{ Arthropoda myriapoda } \\
\hline Diplopoda & 0.15 & 0.36 & 4.0 & 0.049 & & ns & 4.5 & 0.014 \\
\hline Chilopoda & 0.00 & 0.04 & & ns & & ns & & ns \\
\hline Symphyla & 0.00 & 0.00 & & ns & & ns & & ns \\
\hline \multicolumn{9}{|c|}{ Arthropoda chelicerata } \\
\hline Opiliones & 0.08 & 0.11 & & ns & & ns & & ns \\
\hline Aranea & 0.92 & 1.46 & 4.04 & 0.047 & & ns & & ns \\
\hline Acari & 1.12 & 1.38 & & ns & & ns & & ns \\
\hline Gamasida & & & & & & & & \\
\hline $\begin{array}{l}\text { Acari } \\
\text { Oribatida }\end{array}$ & 16.78 & 43.07 & 35.63 & $<0.001$ & 2.81 & 0.066 & & ns \\
\hline $\begin{array}{l}\text { Acari } \\
\text { Prostigmata }\end{array}$ & 0.54 & 0.54 & & ns & & ns & & ns \\
\hline \multicolumn{9}{|c|}{ Arthropoda hexapoda } \\
\hline Collembola & 11.06 & 13.19 & & ns & & ns & & ns \\
\hline Diplura & 0.00 & 0.02 & & ns & & ns & & ns \\
\hline Protura & 0.00 & 0.00 & & ns & & ns & & ns \\
\hline Coleoptera & 0.15 & 0.66 & 7.47 & 0.008 & 3.67 & 0.029 & & ns \\
\hline Coleoptera larvae & 0.00 & 0.21 & & ns & & ns & & ns \\
\hline Dermaptera & 0.02 & 0.02 & & ns & & ns & & ns \\
\hline Dictyoptera & 0.13 & 0.02 & & ns & & ns & & ns \\
\hline Diptera & 0.47 & 1.53 & 3.15 & 0.079 & & ns & & ns \\
\hline Diptera larvae & 0.13 & 0.28 & & ns & & ns & & ns \\
\hline Heteroptera & 0.00 & 0.02 & & ns & & ns & & ns \\
\hline Homoptera & 0.21 & 0.24 & & ns & 4.4 & 0.015 & & ns \\
\hline $\begin{array}{l}\text { Hymenoptera } \\
\text { (formicidae) }\end{array}$ & 1.38 & 1.87 & & ns & & ns & & ns \\
\hline $\begin{array}{l}\text { Other } \\
\text { Hymenoptera }\end{array}$ & 0.21 & 0.26 & & ns & & ns & & ns \\
\hline $\begin{array}{l}\text { Hymenoptera } \\
\text { larvae }\end{array}$ & 0.02 & 0.00 & & ns & & ns & & ns \\
\hline $\begin{array}{l}\text { Total relative } \\
\text { abundance }\end{array}$ & 33.5 & 66.4 & & & & & & \\
\hline $\begin{array}{l}\text { Total } \\
\text { abundance }\end{array}$ & 1558 & 3087 & & & & & & \\
\hline
\end{tabular}

Significant results from two-way ANOVAs of plot, vegetation and their interactions $(P \times V)$ are shown. ns; $p>0.1$ 
Table 3

Relative abundance of the soil faunal groups per plot for soil core samples

\begin{tabular}{|c|c|c|c|c|}
\hline & \multicolumn{2}{|l|}{ soil core } & \multicolumn{2}{|c|}{ Two-way ANOVA * } \\
\hline & Open Forest & $\underline{\text { Dense Forest }}$ & Plot Effect & \\
\hline & Plot & Plot & $\mathrm{F}(1,12)$ & $\mathrm{P}$ \\
\hline \multicolumn{5}{|l|}{ Mollusca } \\
\hline Gasteropoda & 0.00 & 0.00 & & ns \\
\hline Nematoda & 0.03 & 0.06 & & ns \\
\hline \multicolumn{5}{|l|}{ Oligocheta } \\
\hline Enchytraeidae & 0.03 & 0.06 & & ns \\
\hline \multicolumn{5}{|l|}{ Arthropoda crustacean } \\
\hline Isopoda & 0.00 & 0.03 & & ns \\
\hline \multicolumn{5}{|l|}{ Arthropoda myriapoda } \\
\hline Diplopoda & 0.00 & 0.00 & & ns \\
\hline Chilopoda & 0.00 & 0.00 & & ns \\
\hline Symphyla & 0.03 & 0.09 & & ns \\
\hline \multicolumn{5}{|l|}{ Arthropoda chelicerata } \\
\hline Opiliones & 0.00 & 0.00 & & ns \\
\hline Aranea & 0.15 & 0.12 & & ns \\
\hline Acari Gamasida & 4.28 & 6.57 & & ns \\
\hline Acari Oribatida & 22.14 & 36.48 & 4.68 & 0.051 \\
\hline Acari Prostigmata & 0.74 & 2.41 & & ns \\
\hline \multicolumn{5}{|l|}{ Arthropoda hexapoda } \\
\hline Collembola & 15.44 & 10.03 & 5.06 & 0.044 \\
\hline Diplura & 0.06 & 0.00 & & ns \\
\hline Protura & 0.00 & 0.03 & & ns \\
\hline Coleoptera & 0.03 & 0.06 & & ns \\
\hline Coleoptera larvae & 0.00 & 0.09 & & ns \\
\hline Dermaptera & 0.00 & 0.00 & & ns \\
\hline Dictyoptera & 0.00 & 0.00 & & ns \\
\hline Diptera & 0.03 & 0.29 & 21.24 & $<0.001$ \\
\hline Diptera larvae & 0.15 & 0.18 & & ns \\
\hline Heteroptera & 0.03 & 0.00 & & ns \\
\hline Homoptera & 0.33 & 0.03 & & ns \\
\hline Hymenoptera (formicidae) & 0.00 & 0.00 & & ns \\
\hline Other Hymenoptera & 0.00 & 0.00 & & ns \\
\hline Hymenoptera larvae & 0.00 & 0.00 & & ns \\
\hline Total relative abundance & 43.5 & 56.4 & & \\
\hline Total abundance & 1461 & 1900 & & \\
\hline
\end{tabular}

* Neither vegetation effect nor interactions were significant.

leaves, is accompanied by Dryas, Vaccinium or Rhododendron leaves. Below, we observed a Fm horizon of compact matted structure. This Fm horizon was characterized by plant fragments of the litter intermixed by skeletons of the mosses Hylocomium splendens and Rhytidiadelphus squarrosus with abundant fine roots of the living vegetation. Living roots were abundant in the underlying Hh horizon characterised by its dark-brown colour and its massive structure with a greasy character. The Hh horizon consisted of dominant micro- and meso-aggregated fine organic matter ranging from 7 to $33 \mathrm{~cm}$ in thickness (Appendix A). The humus profile ranging from $20 \mathrm{~cm}$ under Dryas to $40 \mathrm{~cm}$ under Vaccinium and Rhododendron was directly developed on the calcareous parent rock.

\subsection{Chemical description of humus forms}

$\mathrm{C} / \mathrm{N}$ ratio was highly correlated with $\mathrm{N}, \mathrm{C}$ and Organic Matter content (Pearson correlation, $r>0.92, p<0.001$ ). Soil $\mathrm{pH}$ was highly correlated to CEC, $\mathrm{Ca}^{2+}$ and base saturation (Pearson correlation, $r>0.84, p<0.001$; mean values of chemical variables are presented in Appendix B). We therefore only described results of $\mathrm{C} / \mathrm{N}$ ratio and $\mathrm{pH}$ as they explained most of the variation observed.

The $\mathrm{C} / \mathrm{N}$ ratio was significantly higher in the DF plot $(p<0.01)$, but not affected by the vegetation nor their interaction. Both, plot $(p<0.001)$ and vegetation $(p<0.001)$ significantly influenced the $\mathrm{pH}$ but also their interaction $(p<0.05)$. The mean $\mathrm{pH}$ was significantly higher on Dryas and Rhododendron subplots of the OF plot. Plot, vegetation and their interaction were not significantly different for the $\mathrm{CaCO}_{3}, \mathrm{Mg}^{2+}, \mathrm{K}^{+}$and $\mathrm{Na}^{+}$.

\subsection{Community structure of soil fauna}

Twenty soil faunal groups were identified from the 90 samples taken from pitfall traps and from the 18 soil cores. Plot location influenced the number of soil animals but not taxonomic richness. Significantly more (about 50\%) individuals were captured by pitfall traps in the warmer DF plot $(p<0.001)$, and about $25 \%$ more individuals $(p=0.403)$ for soil cores. For both methods, Oribatid mites and Collembola dominated the soil fauna and represented about $60 \%$ and $25 \%$ respectively of the total diversity.

For pitfall traps, relative abundance of Oribatid mites $(+17 \%)$, Diplopoda $(+0.5 \%)$, Aranea $(+0.5 \%)$ and Coleoptera $(+0.5 \%)$ was significantly and of Diptera (+1\%) marginally higher in the warmer DF plot (Table 2). Relative abundance of Coleoptea and Homoptera were significantly influenced by the vegetation while Oribatida were only marginally influenced. Soil fauna extracted from soil cores was not affected by vegetation type (Table 3 ). In soil core samples from the warmer DF plots, abundance of Collembola significantly decreased by about 5\%, while Diptera increased about 10 -fold. Relative Oribatida abundance was about $13 \%$ higher, but only marginally significant.

A total of 6 specimens representing 3 genera of earthworms in $\mathrm{OF}$ plot, and 21 specimens representing 4 genera and 6 species in DF plot were extracted from the 24 sampling points (Table 4 ). Diversity of earthworm was very low on OF plots (average 2 ind./ $\mathrm{m}^{2}$ ) and significantly higher on DF plots ( 7 ind. $/ \mathrm{m}^{2}$; $U$-test, $p<0.05$ ), which suggests that earthworms play a limited role in building up the humus structure.

\subsection{Relationships between aggregation and biological activity}

At a micromorphological scale, faunal droppings were observed in the $\mathrm{F}$ and $\mathrm{H}$ horizons. Microaggregates dominated the $\mathrm{F}$ horizon, in which the round excrements of oribatid mites were recognizable, especially those included in skeletons of needles or leaves, together with small irregular faecal pellets of Collembola (Appendix C). Mixtures of micro- and macro-aggregates belonging to several faunal groups such as Diplopoda or Isopoda were clearly observed in the $\mathrm{H}$

Table 4

Relative abundance and relative biomass of earthworms in the plots studied

\begin{tabular}{|c|c|c|c|c|c|}
\hline & \multirow[b]{2}{*}{$\begin{array}{l}\text { Functional } \\
\text { group }\end{array}$} & \multicolumn{2}{|c|}{$\begin{array}{l}\text { Relative } \\
\text { abundance }\end{array}$} & \multicolumn{2}{|c|}{$\begin{array}{l}\text { Relative } \\
\text { biomasse }\end{array}$} \\
\hline & & $\begin{array}{l}\text { Open } \\
\text { Forest }\end{array}$ & $\begin{array}{l}\text { Dense } \\
\text { Forest }\end{array}$ & $\begin{array}{l}\text { Open } \\
\text { Forest }\end{array}$ & $\begin{array}{l}\text { Dense } \\
\text { Forest }\end{array}$ \\
\hline $\begin{array}{l}\text { Dendrobaena octaedra } \\
\text { (Sevigny. } 1826\end{array}$ & epigeic & 0.00 & 4.17 & 0.00 & 1.51 \\
\hline Dendrobaena sp. & epigeic & 0.00 & 4.17 & 0.00 & 0.92 \\
\hline $\begin{array}{l}\text { Dendrodrilus rubidus } \\
\text { (Savigny, 1826) }\end{array}$ & epigeic & 4.17 & 0.00 & 1.33 & 0.00 \\
\hline $\begin{array}{l}\text { Lumbricus friendi Cognetti, } \\
1904\end{array}$ & epianecic & 4.17 & 4.17 & 14.38 & 9.83 \\
\hline $\begin{array}{l}\text { Lumbricus meliboeus Rosa, } \\
1884\end{array}$ & epianecic & 0.00 & 4.17 & 0.00 & 11.90 \\
\hline Lumbricus sp. & epianecic & 8.33 & 29.17 & 6.47 & 23.30 \\
\hline $\begin{array}{l}\text { Nicodrilus caliqinosus } \\
\text { caliqinosus (Savigny, 1826) }\end{array}$ & endogeic & 0.00 & 8.33 & 0.00 & 7.52 \\
\hline $\begin{array}{l}\text { Nicodrilus caliqinosus } \\
\text { tuberculatus (Eisen, 1875) }\end{array}$ & endogeic & 0.00 & 4.17 & 0.00 & 5.06 \\
\hline Nicodrilus sp. & endogeic & 0.00 & 4.17 & 0.00 & 2.27 \\
\hline Octodrilus juvyi Zicsi, 2005 & epigeic & 0.00 & 16.67 & 0.00 & 14.84 \\
\hline \multirow[t]{2}{*}{ Octodrilus sp. } & epigeic & 4.17 & 0.00 & 0.67 & 0.00 \\
\hline & Total & 20.8 & 79.2 & 22.8 & 77.2 \\
\hline
\end{tabular}

$U$-test $(n=12)$ shows significant difference between the two plot for abundance $(p=0.022)$ and for biomass $(p=0.024)$. 


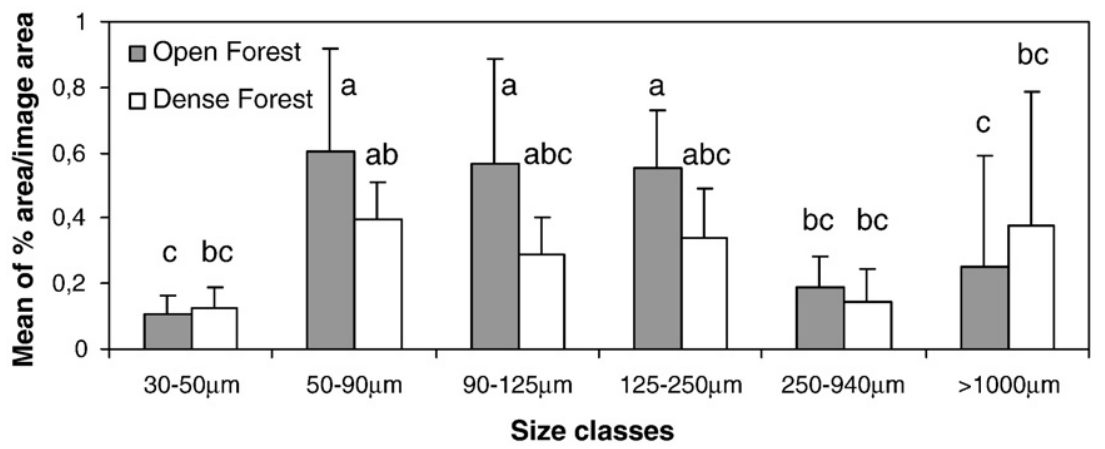

Fig. 3. Mean area and standard error $(n=6)$ occupied by each size classes of biological aggregates from 10 thin section of La Plagne scree in the Open forest (OF plot) and the Dense forest (DF plot). Letters indicate significant differences between size classes after one-way ANOVA ( $p<0.01)$ with Fisher (LSD) test. Means with the same letters are not significantly different.

horizon. A part of the macroaggregates $(>1 \mathrm{~mm}$ ) could be assigned to earthworm activity whereas others, with a more angular shape, were assigned to physical processes.

Using round particle shape as an index of biological aggregation in the image analysis, we compared the evolution of soil fauna aggregates in the humus profile. Our results showed that neither plot nor Fm and Hh horizons had an effect on the distribution of biological aggregates in the site. Differences were observed when aggregates were classified into macroaggregates and microaggregates. The mean area occupied by microaggregates was significantly higher than the area occupied by macroaggregates with a proportion of $2 / 3$ and $1 / 3$ respectively ( $t$-test, $p<0.01$ ). When separating the aggregates

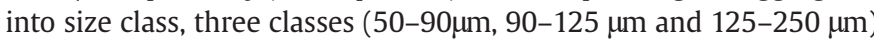
were significantly higher for the OF plot than the others (ANOVA; $p<0.001$; Fig. 3). These biological microaggregates are mostly related to faecal pellets of Collembola (cf. Table 1). Enchytraeids also contribute to these aggregations but it could not be confirmed in our study as no specimens were collected by the extraction method (O'Connor, 1955).

\section{Discussions}

The experiment at the La Plagne scree offers a unique opportunity to assess the long-term effect of a temperature rise similar to the predictions of the IPCC climate scenario A1F1 (IPCC, 2007) on the humus form and the soil fauna. In contrast to most other field studies where the effects of global warming are simulated over a limited number of years (Ineson et al., 1998; Sinclair, 2002; Lindberg and Persson, 2004; Sjursen et al., 2005b), climatic conditions have been similar at La Plagne scree for many centuries. A higher soil temperature (of about $3.8{ }^{\circ} \mathrm{C}$ ) in the DF plots, led to a remarkable change in the soil faunal composition over time, favouring in particular Oribatid mites. However, this altered soil faunal community did not induce a change in the humus structure.

Soil temperature can affect humus form at various levels. The humus form is the result of functional relationships between primary producers and decomposers of the food web, which is affected by changes in environmental conditions. Given the sensitivity of humus forms to temperature, we hypothesize a hierarchical control as described by Aerts (2006) for litter decomposition, with both direct and indirect temperature effects on productivity and soil fauna.

Temperature, particularly in cold biomes, is a limiting factor for biological activities and organic matter decomposition (Berg, 2000; Prescott et al., 2000; Berg and Laskowski, 2005; Kirschbaum, 2006). Based on our observations, we suggest that persistence of temperatures (averaging $4{ }^{\circ} \mathrm{C}$ from June to October and presumably near the freezing point the rest of the year in the OF plot) is the major cause of incomplete decomposition thus limiting soil fauna activity, which leads to humimor formation.
Secondly, soil temperature indirectly affects plant growth which ceases below species specific thresholds. In the OF plot, low soil temperature may constraint the growth of Mountain pine by inhibiting root or shoot meristem activity as observed on dwarf red spruces in a similar ecosystem (Körner and Hoch, 2006). However, mean temperature above $7{ }^{\circ} \mathrm{C}$ (as in the DF plot) favours plant growth and may increase the input of recalcitrant leaf litter of acidophilic plants. This may explain the increase in soil acidity and the higher $\mathrm{C} / \mathrm{N}$ ratio in the DF plot. Our results may be seen as the long-term response to soil warming on the boreo-alpine vegetation of the scree and confirms results of short-term experiments which showed shifts in plant growth with increasing soil temperature (Chapin et al., 1995; Jarvis and Linder, 2000; Brooker and Van Der Wal, 2003). We consider that the effect of temperature on humus form operates indirectly on the organic matter decomposition rates through the change in plant community structure.

Moreover, temperature may induce changes in the species composition and structure of decomposer and detritivore communities in the long-term. At our site, the soil faunal group (Oribatid mites and Collembola) that reacted to higher temperature is small in size and has low dispersal power. Nevertheless, changes in those two dominant communities have to date not induced a change in the humus structure. This may be explained by the extraordinary complexity of biotic interactions between components of soil food webs (Berg et al., 2001; Bardgett, 2002; Moore et al., 2004).

In the scarcity of earthworms, Collembola and Acari are significant contributors to decomposition processes, presumably in addition to Enchytraeids and Nematodes, as shown in arctic and alpine regions (Sjursen et al., 2005a). These decomposer organisms are commonly favoured in humus with important organic matter accumulation. However, no Enchytraeids have been found in our study. On the other hand, the humus thin sections which indicate a high Collembola and Enchytraeid activity, underline the importance of the micro- and meso-fauna. Moreover, results of the soil cores and pitfall traps indicate an important contribution by Acari which is not reflected by the analysis of the humus thin sections. The systematic analysis used to separate plant debris from biological aggregates on the basis of the shape index does not take into account faecal pellets of Acari produced in the skeleton of leaves (cf. App 3) because irregular and elongated shapes of plant debris are excluded. This creates a bias relating to Acari activity in the size class $30-50 \mu \mathrm{m}$, for which the mean area occupied may be underestimated. The Collembola abundance in the pitfalls was also similar for both plots whereas the number of Collembola specimens significantly decreased in the soil cores. This may be explained by the different information on invertebrate community given by these two methods. Pitfall traps tended to catch the large surface-active species while soil core samples give a quantitative estimate of soil dwelling species more susceptible to react to soil temperature variations which is strongly reflected by the Collembola (Dollery et al., 2006). Our results are therefore similar to those found 
by several other authors in soil warming experiments of boreal and arctic ecosystems where warming led to decreases in Collembola and increases in Oribatida (Lindberg et al., 2002; Haimi et al., 2005; Sjursen et al., 2005b; Dollery et al., 2006; McGeoch et al., 2006).

\section{Conclusion}

Our work is among the first that details the ecological components of the alpine ecosystems developed on frozen screes and confirms the importance of spatial and temporal scales in measuring an ecosystem response to environmental change.

In our natural ecosystem, higher soil temperature led to a different soil faunal composition over time. Nevertheless, soil faunal variations do not affect the humus form which remains similar on the entire scree. This suggests the need of further investigations on soil species response to changing climate and the impact on soil nutrient dynamics. Several studies have been focused on polar or alpine ecosystems (Marion et al., 1997; Hodkinson and Wookey, 1999; Sjursen et al., 2005b), whereas fewer studies looked at the temperate fauna.
Alpine ecosystems of frozen screes appear to be well adapted for such investigations allowing comparisons to be made with previous works on similar communities in high latitudinal and altitudinal regions.

In conclusion, works on these alpine enclaves could help to predict the effects of changes in soil temperature on the alpine belt and to measure the magnitude of induced process shifts, such as faunal response.

\section{Acknowledgements}

We are very grateful to the Parc Naturel Régional de Chartreuse and to the Réserve Naturelle des Hauts de Chartreuse for allowing us access to the La Plagne's scree. George Rovera from Institut de Géographie Alpines (Grenoble) is thanked for the stimulation from discussions at the start of the work on frozen scree slopes. We wish to thank Faycal Soufi from Savoy University for the inclusions of humus blocks and for the preparation of the thin sections and two anonymous reviewers for valuable comments on the manuscript, and Chloe Molineux who revised the English. CEMAGREF provided financial support and logistics for field works.

Appendix A. Morphological features of humus forms developed on La Plagne's frozen scree.

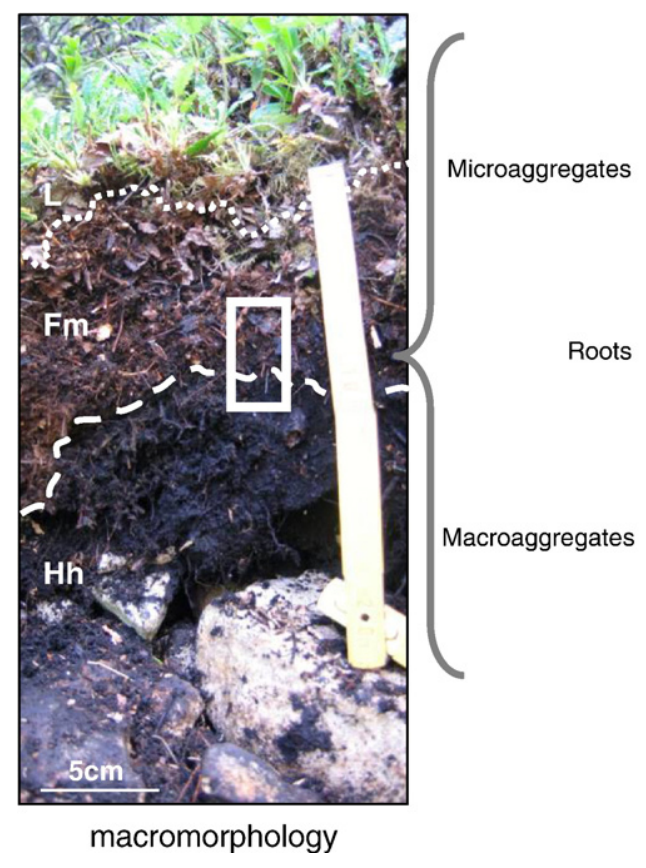

\section{F Horizon}

* Compact matted structure dominated by plant materials (detritus, roots)

* Scattered fine organic matter

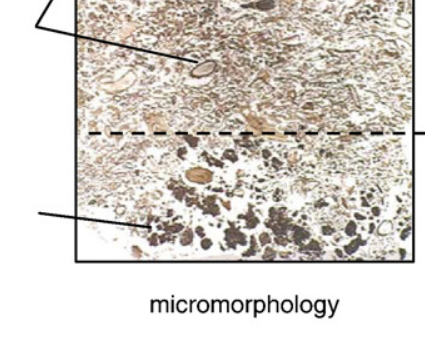

\section{Hh Horizon \\ * Greasy massive structure \\ * Plant materials (few detritus, much roots) \\ * micro- and macro-aggregation}

\section{Appendix B.}

Mean \pm standard error, minimum and maximum value for soil chemical parameters significantly different between the Open Forest (OF) plot and the Dense Forest (DF) plot

\begin{tabular}{|c|c|c|c|c|c|c|c|c|c|c|c|c|}
\hline & \multicolumn{3}{|l|}{$\mathrm{OF}(n=9)$} & \multicolumn{3}{|l|}{$\mathrm{DF}(n=9)$} & \multicolumn{6}{|c|}{ Two-way ANOVA } \\
\hline & \multirow[t]{2}{*}{ Mean \pm SE } & \multirow[t]{2}{*}{ Min } & \multirow[t]{2}{*}{ Max } & \multirow[t]{2}{*}{ Mean \pm SE } & \multirow[t]{2}{*}{ Min } & \multirow[t]{2}{*}{ Max } & \multicolumn{2}{|l|}{ Plot } & \multicolumn{2}{|c|}{ Vegetation } & \multicolumn{2}{|l|}{$P \times V$} \\
\hline & & & & & & & $F(1,12)$ & $\mathrm{p}$ & $F(2,12)$ & $\mathrm{p}$ & $\mathrm{F}(2,12)$ & $\mathrm{p}$ \\
\hline $\mathrm{N}(\mathrm{g} / \mathrm{kg})$ & $15.28 \pm 0.18$ & 14.7 & 16.6 & $13.42 \pm 0.42$ & 11.2 & 15.5 & 16.25 & 0.0016 & & & & \\
\hline $\mathrm{C} / \mathrm{N}$ & $24.11 \pm 0.57$ & 22.1 & 28.1 & $31.39 \pm 1.78$ & 24.0 & 41.3 & 14.80 & 0.0023 & & & & \\
\hline $\mathrm{C}(\mathrm{g} / \mathrm{kg})$ & $368.78 \pm 8.93$ & 340.0 & 424.0 & $415.44 \pm 11.70$ & 364.0 & 463,0 & 11.09 & 0.0059 & & & & \\
\hline Organic matter (g/kg) & $637.89 \pm 15.59$ & 587.0 & 734.0 & $718.44 \pm 20.23$ & 630.0 & 801,0 & 10.95 & 0.0062 & & & & \\
\hline pH H2O & $6.23 \pm 0.22$ & 5.2 & 7.1 & $4.87 \pm 0.17$ & 4.31 & 5.85 & 75.91 & 0.0000 & 15.03 & 0.0005 & 5.20 & 0.0236 \\
\hline $\mathrm{CEC}(\mathrm{cmol}+/ \mathrm{kg})$ & $107.45 \pm 3.26$ & 95.1 & 121.0 & $89.34 \pm 1.41$ & 84.3 & 95.5 & 50.68 & 0.0000 & 4.42 & 0.0364 & 5.19 & 0.0237 \\
\hline $\mathrm{Ca}(\mathrm{cmol}+/ \mathrm{kg})$ & $92.43 \pm 5.93$ & 63.6 & 113.0 & $45.48 \pm 8.83$ & 0.8 & 89.3 & 36.43 & 0.0000 & 7.40 & 0.0080 & & \\
\hline Base saturation (\%) & $90.99 \pm 3.49$ & 72.4 & 103.6 & $55.84 \pm 10.03$ & 1.96 & 107.2 & 17.29 & 0.0013 & 5.53 & 0.0198 & & \\
\hline
\end{tabular}




\section{Appendix C. Round faecal pellets of Oribatida (a) in a leaf of Dryas and irregular faecal pellets of Collembola $($ size $<90 \mu \mathrm{m})$ (b) observed in the Humimor from La Plagne's scree.}

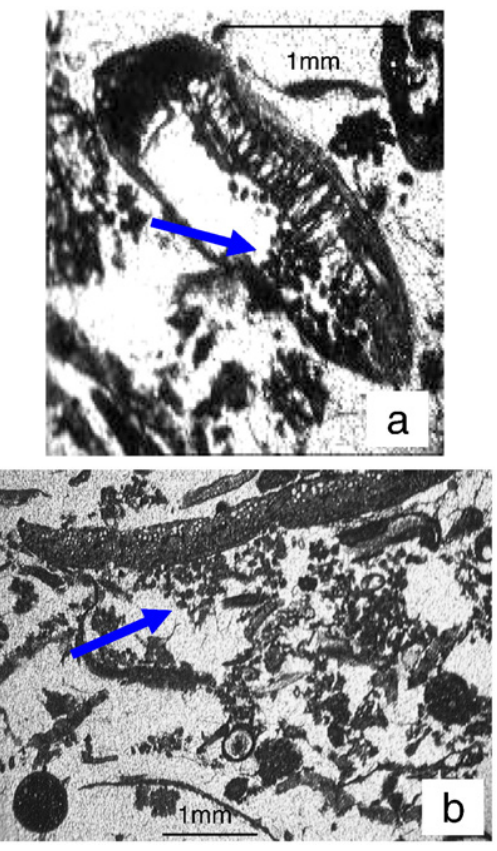

\section{References}

Aerts, R., 2006. The freezer defrosting: global warming and litter decomposition rates in cold biomes. Journal of Ecology 94, 713-724.

Asta, J., Orry, F., Toutain, F., Souchier, B., Villemin, G., 2001. Micromorphological and ultrastructural investigations of the lichen-soil interface. Soil Biology and Biochemistry 33, 323-337.

Bardgett, R.D., 2002. Causes and consequences of biological diversity in soil. Zoology 105, 367-375.

Beniston, M., 2006. Mountain weather and climate: A general overview and a focus on climatic change in the Alps. Hydrobiologia 562, 3-16.

Berg, B., 2000. Litter decomposition and organic matter turnover in northern forest soils. Forest Ecology and Management 133, 13-22.

Berg, M.P., et al., 2001. Community food web, decomposition and nitrogen mineralisation in a stratified Scots pine forest soil. Oikos, 94, 130-142.

Berg, B., Laskowski, R., 2005. Litter decomposition: A guide to carbon and nutrien turnover. Advances in Ecological Research, vol. 38. Academic Press. 1-428 pp.

Bertinelli, F., Petitcolas, V., Asta, J., Richard, L., Souchier, B., 1993. Relations dynamiques entre la végétation et le sol sur éboulis froid dans les Alpes françaises méridionales. Revue d'Ecologie Alpine 2, 93-104.

Brooker, R., Van Der Wal, R., 2003. Can soil temperature direct the composition of high arctic plant communities? Journal of Vegetation Science 14, 535-542.

Bruneau, P.M.C., Davidson, D.A., Grieve, I.C., 2004. An evaluation of image analysis for measuring changes in void space and excremental features on soil thin sections in an upland grassland soil. Geoderma 120, 165-175.

Callaham, M.A., Hendrix, P.F., 1997. Relative abundance and seasonal activity of earthworms (Lumbricidae and Megascolecidae) as determined by hand-sorting and formalin extraction in forest soils on the southern Appalachian Piedmont. Soil Biology and Biochemistry 29, 317-321.

Chapin, F.S., Shaver, G.R., Giblin, A.E., Nadelhoffer, K.J., Laundre, J.A., 1995. Responses of arctic tundra to experimental and observed changes in climate. Ecology 76, 694-711.

Dollery, R., Hodkinson, I.D., Jonsdottir, I.S., 2006. Impact of warming and timing of snow melt on soil microarthropod assemblages associated with Dryas-dominated plant communities on Svalbard. Ecography 29, 111-119.

FitzPatrick, E.A., 1980. The micromorphology of soils. A manual for the preparation and description of thin sections of soils. Dept. of Soil Science, University of Aberdeen, U.K.

Green, R.N., Trowbridge, R.L., Klinka, K., 1993. Towards a taxonomic classification of humus forms. Forest Science 39, 1-48.

Grieve, I.C., Davidson, D.A., Bruneau, P.M.C., 2005. Effects of liming on void space and aggregation in an upland grassland soil. Geoderma 125 (1-2), 39-48.

Gude, M., et al., 2003. Probable occurrence of sporadic permafrost in non-alpine scree slopes in central Europe. Proceedings 8th International Conference on Permafrost. Zürich, pp. 331-336.

Haimi, J., et al., 2005. Impacts of elevated $\mathrm{CO}_{2}$ and temperature on the soil fauna of boreal forests. Applied Soil Ecology 30, 104-112.
Harris, S.A., Pedersen, D.E., 1998. Thermal regimes beneath coarse blocky materials. Permafrost and Periglacial Processes 9, 107-120.

Hodkinson, I.D., Wookey, P.A., 1999. Functional ecology of soil organisms in tundra ecosystems: towards the future. Applied Soil Ecology 11, 111-126.

Huhta, V., Hanninen, S.-M., 2001. Effects of temperature and moisture fluctuations on an experimental soil microarthropod community. Pedobiologia 45, 279-286.

Ineson, P., et al., 1998. Effects of climate change on nitrogen dynamics in upland soils. 2. A soil warming study. Global Change Biology 4, 153-161.

IPCC, 2007. Summary for Policymakers. In: Solomon, S., Qin, D., Manning, M., Chen, Z. Marquis, M., Averyt, K.B., Tignor, M., Miller, H.L. (Eds.), Climate Change 2007: The Physical Science Basis. Contribution of Working Group I to the Fourth Assessment Report of the Intergovernmental Panel on Climate Change. Cambridge University Press, Cambridge.

ISO 10693, 1999. Qualité du sol - Détermination de la teneur en carbonate - Méthode volumétrique. In: Collectif AFNOR (Ed.), Qualité des sols. . Méthodes d'analyse chimique, vol. 1. AFNOR, Paris.

ISO 10694, 1999. Qualité du sol - Dosage du carbone organique et du carbone tota après combustion sèche (analyse élémentaire). In: Collectif AFNOR (Ed.), Qualité des sols. . Méthodes d'analyse chimique, vol. 1. AFNOR, Paris.

ISO 13878, 1999. Qualité du sol - Détermination de la teneur totale en azote par combustion sèche ("analyse élémentaire”). In: Collectif AFNOR (Ed.), Qualité des sols. . Méthodes d'analyse chimique, vol. 1. AFNOR, Paris.

Jarvis, P., Linder, S., 2000. Constraints to growth of boreal forests. Nature 405, 904-905. Kirschbaum, M.U.F., 2006. The temperature dependence of organic-matter decomposition - still a topic of debate. Soil Biology and Biochemistry 38, 2510-2518.

Kneisel, C., Hauck, C., Vonder Mühll, D., 2000. Permafrost below the timberline confirmed and characterized by geoelectrical resistivity measurements, Bever Valley, Eastern Swiss Alps. Permafrost and Periglacial Processes 11, 295-304.

Kooistra, M.J., 1991. A micromorphological approach to the interactions between soil structure and soil biota. Agriculture. Ecosystems \& Environment 34 (1-4), 315-328.

Körner, C., Hoch, G., 2006. A test of treeline theory on a montane permafrost island. Arctic. Antarctic, and Alpine research 38, 113-119.

Lindberg, N., Persson, T., 2004. Effects of long-term nutrient fertilisation and irrigation on the microarthropod community in a boreal Norway spruce stand. Forest Ecology and Management 188, 125-135.

Lindberg, N., Engtsson, J.B., Persson, T., 2002. Effects of experimental irrigation and drought on the composition and diversity of soil fauna in a coniferous stand. Journal of Applied Ecology 39, 924-936.

Marion, G.M., et al., 1997. Open-top designs for manipulating field temperature in highlatitude ecosystems. Global Change Biology 3, 20-32.

McGeoch, M.A., Le Roux, P.C., Hugo, E.A., Chown, S.L., 2006. Species and community responses to short-term climate manipulation: Microarthropods in the subAntarctic. Austral Ecology 31, 719-731.

Metson, A.J., 1956. Methods of chemical analysis for soil survey samples. NZ Soil Bur Bul 12

Molenda, R., 1996. Zoogeographische Bedeutung Kaltluft erzeugender Blockhalden im auberalpinen Mitteleuropa: Untersuchungen an Arthropoda, insbesondere Coleoptera. Verh. naturwiss. Ver. Hamburg, 35, 5-93.

Moore, J.C., et al., 2004. Detritus, trophic dynamics and biodiversity. Ecology Letters, 7 , 584-600.

Noss, R.F., 2001. Beyond Kyoto: forest management in a time of rapid climate change. Conservation Biology 15, 578-590.

Nekola, J.C., 1999. Paleorefugia and neorefugia: the influence of colonization history on community pattern and process. Ecology 80, 2459-2473.

O'Connor, F.B., 1955. Extraction of enchytraeid worms from a coniferous forest soil. Nature 175, 815-816.

Pawluk, S., 1987. Faunal micromorphological features in moder humus of some Western Canadian soils. Geoderma 40, 3-16.

Petersen, H., Luxton, M., 1982. A comparative analysis of soil fauna populations and their role in decomposition processes. Oikos 39, 288-388.

Pflug, A., Wolters, V., 2001. Influence of drought and litter age on Collembola communities. European Journal of Soil Biology 37, 305-308.

Post, W.M., Emanuel, W.R., Zinke, P.J., Stangenberger, A.G., 1982. Soil carbon pools and world life zones. Nature 298, 156-159.

Prescott, C.E., Maynard, D.G., Laiho, R., 2000. Humus in northern forests: friend or foe? Forest Ecology and Management 133, 23-36.

Rusek, J., 1985. Soil microstructures - contributions on specific soil organisms. Quaestiones Entomologicae 21, 497-514.

Ruzicka, V., Zacharda, M., 1994. Arthropods of stony debris in the Krkonose Mountains. Czech Republic. Arctic and Alpine Research, 26, 332-338.

Schaller, F., 1968. Soil animals. The University of Michigan Press, Ann Arbor, USA.

Setälä, H., Marshall, V.G., Trofymow, J.A., 1995. Influence of micro- and macro-habitat factors on collembolan communities in Douglas-fir stumps during forest succession. Applied Soil Ecology 2, 227-242.

Sinclair, B.J., 2002. Effects of increased temperatures simulating climate change on terrestrial invertebrates on Ross Island. Antarctica. Pedobiologia, 46, 150-160.

Sjursen, H., Michelsen, A., Holmstrup, M., 2005a. Effects of freeze-thaw cycles on microarthropods and nutrient availability in a sub-arctic soil. Applied Soil Ecology 28, 79-93.

Sjursen, H., Michelsen, A., Jonasson, S., 2005b. Effects of long-term soil warming and fertilisation on microarthropod abundances in three sub-arctic ecosystems. Applied Soil Ecology 30, 148-161.

Sulkava, P., Huhta, V., 2003. Effects of hard frost and freeze-thaw cycles on decomposer communities and $\mathrm{N}$ mineralisation in boreal forest soil. Applied Soil Ecology 22, 225-239. 
Tape, K.E.N., Sturm, M., Racine, C., 2006. The evidence for shrub expansion in Northern Alaska and the Pan-Arctic. Global Change Biology 12, 686-702.

Theurillat, J.P., Guisan, A., 2001. Potential impact of climate change on vegetation in the european Alps: a review. Climatic Change 50, 77-109.

Thomas, C.F.G., Marshall, E.J.P., 1999. Arthropod abundance and diversity in differently vegetated margins of arable fields. Agriculture. Ecosystems \& Environment, 72 (2), 131-144.

Thompson, W.F., 1962. Preliminary notes on the nature and distribution of rock glaciers relative to true glaciers and other effects of the climate on the ground in North America. In: Ward, W. (Ed.), Symposium at Obergurgl, vol. 58. International Association of Scientific Hydrology Publication, Obergurgl, Austria, pp. 212-219.
United States Department of Agriculture and Natural Resources Conservation Service (USDA), 1999. Soil taxonomy a basic system of soil classification for making and interpreting soil surveys. Agriculture Handbook, vol. 436. Soil Survey Staff, Washington DC.

Zacharda, M., et al., 2005. The relict mite Rhagidia gelida (Acari, Rhagidiidae) as a biological cryoindicator of periglacial microclimate in European highland screes. Arctic, Antarctic and Alpine Research, 37, 402-408. 